\title{
The Effect of Massed Practice Methods and Distributed Practice Methods on Improving Forehand Drive Skills in Tennis
}

\author{
Yudi Nurcahya*, Widi Kusumah, Patriana Nurmansyah \\ Pendidikan Kepelatihan Olahraga \\ Universitas Pendidikan Indonesia \\ Bandung, Indonesia \\ *udinurcahya@upi.edu, widikusumah@upi.edu, Patriananurmansyah@upi.edu
}

\begin{abstract}
This study aims to determine differences in the effect of massed practice methods and distributed practice methods on improving tennis forehand drive skills. This study used an experimental method of 20 students who took tennis practice at school. The instrument for data collection in this study used the Forehand Drive Tennis skills test with a validity of 0.74 and a reliability of 0.85 . The results of this study indicate that the distributed practice method has a more significant effect compared to the massed practice method on improving tennis forehand drive skills. This is because the distributed practice method is given time to rest, so that the quality of the student's stroke is maintained. This research can be a reference for tennis coaches to use this exercise to improve athlete performance on the field.
\end{abstract}

Keywords: distributed practice, massed practice, tennis performance

\section{INTRODUCTION}

In this modern age of sports, tennis is one of the sports that is popular and popular with people in the world, both men and women, ranging from children to adults, this is indicated by the number of tennis courts and people who does tennis. Tennis is a sport based on uncertainty. The uncertainty of point length, shots, strategy, match duration, weather, and opponents all influence the physiological aspects of playing tennis [1-3]. Tennis is an individual game that can be done by one person against one person (single) or two people against two people (double). Tennis, unlike many other sports, does not have a match time limit. It can produce matches that last less than an hour or as long as five hours [4]. For this reason the physical quality of a tennis player greatly influences the game on the field. The average heart rate in trained players aged 20 to 30 years ranges from 140-160 pulses per minute during a single tennis competition match, this shows an overall intensity of 60$70 \%$ of $\mathrm{VO} 2 \max [5,6]$. Tennis is a sport characterized by a combination of physical actions. These actions include running at different speeds, deceleration, acceleration, change of direction, sprints, punches, shearing, and involvement of the upper arm [7].

Achievement of an achievement, especially in tennis, is largely determined by several determining factors. In this regard, there are four aspects of training that need to be carefully considered and trained by athletes, namely (a) physical training, (b) technical training, (c) tactic training, and (d) mental training [7]. In tennis, the ability of a player is determined by a good mastery of basic techniques [8,9]. Therefore mastery of basic techniques is necessary so that achievement can be improved. The perfection of the basic techniques of every sports movement is important. That will determine the overall movement. Therefore, the basic movements of every form of technique needed in every sport must be perfectly trained and mastered.

In an effort to achieve the goal of the game of tennis, which is to kill the ball in the opponent's area, and try to defend their own area from the opponent's attack. To make it easier to reach the goal in the game of tennis is to do a variety of attacks, both from the attack line, back line, or even from the service area. One method that can be used to carry out attacks is to practice forehand drive skills. For beginners, the backhand and forehand drive must be mastered first before practicing and mastering other types of punches. By practicing and mastering the drive punch a tennis player will learn and try to lay the foundations of a solid punch in tennis and become the basis for building another punch [10]. Of all the strokes in a game, three quarters of the winning strokes are determined by the forehand [11]. Forehand is the most common stroke used in tennis. In essence, a player can win a match or game (set) if he can hit the forehand hard and the opponent cannot return or the opponent can return a bad forehand drive which can be the decider of victory in the match.

There are many methods that can be used to practice skills. But often the trainer uses just the same training methods. Though the trainer has many training methods that can be given to athletes. Associated with the use of time in the training process, the training methods that can be used are solid training methods and distributed training methods. The real difference between the two training methods is the involvement of fatigue in one of them. As a result, it decreases the appearance of the following tests and may even interfere with the training process that can usually occur at this stage. Based on the background explanation of the problem above, the authors feel interested in examining the basic technical skills of forehand drive in tennis 
by writing in a research title, namely "The effect of massed practice methods and distributed practice methods are to increase of forehand drive skills in tennis."

\section{METHOD}

\section{A. Participant}

The population in this study were students who participated in tennis extracurricular activities at SMA NEGERI 3 CIMAHI as many as 14 people. Sampling in this study using a total sampling technique, so that the total population of 14 people used as research samples. The 14 samples will be divided into two experimental groups after conducting the initial test forehand drive tennis skills. The two experimental groups are the experimental group with the solid training method and the experimental group with the distributed training method.

\section{B. Preliminary Measurements}

All samples conducted initial tests of forehand drive tennis skills with validity of 0.74 and reliability of 0.85 . The sample stands in the middle of the finish line, the trainer, or a helper takes a position across the net in the middle of the service. The helper hits the ball five times that falls in the service box to warm up. Then the sample performs a 10-ball test for the forehand. Sample tries to hit the ball over the net that is directed to the field on the other side that has been given a number. For the objectivity of the test if possible the one who gives the ball (helper) must be the same for all test takers. Balls that fall on the target are given the numbers 5,4,3,2. If the ball passes over the rope is given half the number of the target box on the ball. After obtaining the results of the initial test, the sample was divided into 2 groups using simple random sampling technique. The sample will be divided into two experimental groups, namely the experimental training group using the massed method and the experimental group using the distributed training method.

\section{Experimental Implementation}

All samples did exercise for 8 weeks, then in 1 week 3 meetings, so the number of meetings was 24 times. After conducting experiments for the next 24 meetings, final test forehand drive tennis was conducted to determine whether there was an increase in training results.

\section{RESULT}

Data obtained from test results and measurements are still not meaningful and are raw scores. To get a conclusion or meaning from the data, the data must be processed and analysed statistically.

TABle I. Results Of CAlCUlation Of Average VAlue For FOREHAND SKILL TEST

\begin{tabular}{|l|l|l|l|}
\hline \multicolumn{1}{|c|}{ Group } & \multicolumn{1}{c|}{ Pre test } & \multicolumn{1}{c|}{ Post test } & Gain \\
\hline Massed practice & 15,86 & 21,5 & 5,64 \\
\hline Distributed practice & 15,78 & 23,64 & 7,86 \\
\hline
\end{tabular}

Table 1 shows that the average initial test score of the forehand drive training group with the massed training method is 15.86 higher than the average forehand drive training group with the distributed training method of 15.78 . The final test showed that the average score of the forehand drive exercise group with the distributed training method was 23.64 higher than the average score of the forehand drive group with the massed training method of 21.5. 3. Table 1 also shows that the gain or difference between the results of the initial and final tests of the two groups, namely the average gain score of the forehand drive group with the massed training method of 5.64 is lower than the average gain score of the forehand group of the exercise group drive with a distributed training method of 7.86 .

The next step is to test the analysis of test data from the two test results on the sample (testing and analysis is to find out whether there is a significant increase in training results from both groups of samples). The results of statistical analysis can be seen in Table 2 .

TABLE II. CALCUlation RESUlts AND SignifiCANCE TESTS FOR IMPROVING TRAINING RESULTS OF BOTH GROUPS

\begin{tabular}{|l|l|l|l|}
\hline \multicolumn{1}{|c|}{ Gain } & \multicolumn{1}{|c|}{ t-count } & \multicolumn{1}{c|}{ t-table } & \multicolumn{1}{c|}{ result } \\
\hline $\begin{array}{l}\text { Forehand drive with } \\
\text { massed practice }\end{array}$ & 10,64 & 2,45 & Significant \\
\hline $\begin{array}{l}\text { Forehand drive with } \\
\text { distributes practice }\end{array}$ & 16,37 & 2,45 & Significant \\
\hline
\end{tabular}

Calculations and tests of a significant improvement in the results of the form of exercise are carried out using a significant test of the similarity of the two average tests of the two parties namely the t-test. From the test results shown in Table 2, it was found that:

- For the form of forehand drive training using the massed training method, the value of $\mathrm{t}$ arithmetic (10.64) $>\mathrm{t}$ table $(2.45)$ is significant $/ \alpha=0.05$ with $\mathrm{dk}$ (6). Test criteria are, accept the hypothesis if $-t-1-1 / 2 \alpha<t$ count $<\mathrm{t} 1-1 / 2 \alpha$. In this case, the $t$-count is in the area of rejection of Ho, meaning that Ho is rejected. The conclusion is that there is a significant influence of the form of forehand drive training with massed training methods on increasing mastery of forehand drive skills in tennis.

- For the form of forehand drive training with the distributed training method, the value of $t$ arithmetic (16.37) $>\mathrm{t}$ table (2.45) is significant / $\alpha=0.05$ with $\mathrm{dk}$ (6). Test criteria are, accept the hypothesis if $-\mathrm{t} 1-1 / 2 \alpha<\mathrm{t}$ count $<\mathrm{t} 1-1 / 2 \alpha$. In this case, the $\mathrm{t}$-count is in the area of rejection of Ho, meaning that $\mathrm{Ho}$ is rejected. The conclusion is that there is a significant influence of the form of forehand drive training with a distributed training method to improve mastery of forehand drive skills in tennis.

The next step is to test the exercise model that gives a more significant effect by using the two-party average similarity test, the t-test. The test results can be seen in Table 3 . 
TABLE III. TEST RESUlts SignifiCANCE OF THE DifFERENCE IN IMPROVEMENT OF BOTH EXERCISE METHODS

\begin{tabular}{|l|l|l|l|}
\hline & \multicolumn{1}{|c|}{ t-count } & t-table & result \\
\hline $\begin{array}{l}\text { Forehand drive with } \\
\text { massed practice methods }\end{array}$ & & & \\
$\begin{array}{l}\text { and distributed practice } \\
\text { methods }\end{array}$ & $-3,08$ & 2,18 & $\begin{array}{l}\text { Significa } \\
\mathrm{nt}\end{array}$ \\
\hline
\end{tabular}

From the test results obtained that $t$ arithmetic $(-3.08)$. The test criterion is accept Ho if $-\mathrm{t} 1-1 / 2 \alpha<\mathrm{t}$ count $<\mathrm{t} 1-1 / 2 \alpha$ at the real level $\alpha=0.05$ with $(\mathrm{dk})=12$. In this case, $t$ arithmetic is in the rejection region, the hypothesis is rejected. In conclusion, there is a significant difference in the effect of forehand training with massed training methods and distributed training methods that contribute to improving mastery of forehand drive skills in tennis. This means that forehand drive training with distributed training methods has a more significant influence on improving mastery of forehand drive skills in tennis because the forehand drive training with distributed training methods has an average increase of 7.86 which is greater than the average score - average forehand drive training with a massed training method which increased by 5.64 .

\section{CONCLUSION}

Based on the results of data processing and analysis, the conclusions from the results of this study are as follows: There is a significant influence of solid training methods on increasing mastery of forehand drive skills. There is a significant effect of distributed training methods on improving mastery of forehand drive skills. There is a significant difference in the effect between the solid training method and the distributed training method to improve mastery of forehand drive skills in tennis. After comparing it turns out that the distributed training method gives a more significant effect on increasing mastery of forehand drive skills in tennis. This can be seen from the results of the exercise with the method of distributing the average value of an increase of 7.86 is greater than the training with the solid method of getting an average increase of 6.14.

\section{DISCUSSION}

Based on the research results obtained a significant effect of forehand training with massed training methods on increasing mastery of forehand skills in tennis. This is because the solid training method allows students to do a lot of repetition of motion so that the automation of motion can be formed, and the training material is adjusted to the training conditions, especially the condition of the students. But there is a weakness in the method of massed training where students quickly experience fatigue when repeating a lot of motion tasks. With the fatigue that is felt by students when repeating the task of moving the conditional reflexes cannot be achieved properly.

Forehand drive training with distributed training methods has a significant influence on improving mastery of forehand drive skills in tennis. This is due to the fact that the distributed training method allows students to do the task of training with plenty of rest time so that students can concentrate more on the training and fatigue when practicing does not occur. Because there is no meaningful fatigue during practice making conditional reflexes can be achieved.

There is a significant difference in effect between forehand training with massed training methods and distributed training methods to improve mastery of forehand drive skills in tennis. Distributed training methods have a better effect than massed training methods on increasing mastery of forehand drive skills in tennis. This is because distributed training gives a lot of rest time so that the process of fatigue in practice will not occur and conditional reflexes can be maintained so as to ensure the automation of the movements carried out the rest period that allows for an increase in performance [12]. This difference occurs because groups that use the distributed practice approach practice more intensively and effectively so as to obtain better learning outcomes, while groups that use the massed practice approach cannot demonstrate their ability because they experience fatigue [13].

The results of this study prove that motor activities carried out continuously and systematically and in accordance with the demands of the task to be performed (sports branches) will give good results. In order for specific motor activities to have a good influence on exercise, the exercise must be based on two things, namely a) doing exercises that are specific to that specialized sport, b) doing exercises to develop biomotoric abilities that are required by these sports [14].

The results of this study illustrate that the method of solid and distributed training provides support for student achievement. But there are many factors that also determine the results of training not only training methods, such as physical conditions and technical factors. Both of these points indicate a relatively large association with athlete performance. Success in sports often requires perfect performance in situations of high physical stress, so it is increasingly clear that physical conditions play a very important role in increasing athlete performance [14].

\section{REFERENCES}

[1] M. Kovacs, "Energy system-specific training for tennis," Strength Condition J, vol. 26, pp. 10-13, 2004.

[2] S.J. Douvis, "Variable practice in learning the forehand drive in tennis," Perceptual and motor skills, vol. 101(2), pp. 531-545, 2005.

[3] R.E. Bahamonde and D. Knudson, "Kinetics of the upper extremity in the open and square stance tennis forehand," Journal of Science and Medicine in Sport, vol. 6(1), pp. 88-101, 2003.

[4] B. Dawson, B. Elliott, F. Pyke, "Physiological and performance responses to playing tennis in a cool environment and similar intervalized treadmill running in a hot climate," J Hum Mov Stud, vol. 11, pp. 21-34, 1985.

[5] M.F. Bergeron, C.M. Maresh, W.J. Kraemer, A. Abraham, B. Conroy, And C. Gabaree, "Tennis: a physiological profile duringmatch play," Int. J. Sports Med, vol. 12, pp. 474-479, 1991.

[6] B. Elliott, B. Dawson and F. Pyke, "The energetics of single tennis," J. Hum. Mov. Stud, vol. 11, pp. 11-20, 2005.

[7] B. Kilit, E. Arslan, "Effects Of High-Intensity Interval Training Vs OnCourt Tennis Training In Young Tennis Players," Journal of Strength and Conditioning Research, vol. 33(1), pp. 188-196, 2018.

[8] H.A. Riemer and K. Toon, "Leadership and satisfaction in tennis: Examination of congruence, gender, and ability," Research Quarterly for Exercise and Sport, vol. 72(3), pp. 243-256, 2001. 
[12] Robert N. Singer, "Massed and Distributed Practice Effects on the Acquisition and Retention of a Novel Basketball Skill," Research Quarterly, American Association for Health, Physical Education and Recreation, vol. 36(1), pp. 68-77, 2013.

[13] R. Lutan, Pengantar Belajar Keterampilan Motorik. Jakarta: Depdikbud, 2000.

[14] Harsono, Coaching dan Aspek-Aspek psikologis dalam coaching. Jakarta : CV. Tambak Kusuma, 1998. 